\title{
ENVIRONMENTAL STUDIES ON THE IMPACT OF THE DRAINS EFFLUENT UPON THE SOUTHERN SECTOR OF LAKE MANZALAH, EGYPT
}

\author{
Amaal M. Abdel - Satar \\ National Institute of Oceanography and Fisheries, Inland Water \\ Branch, Egypt.
}

Key Words: Water pollution, urban and agricultural wastes, trace metals, Lake Manzalah, Egypt

\section{ABSTRACT}

$\mathbf{E}$ ffect of the drains effluent on the variations of trace metals and inorganic anions and cations of water were studied in the southern sector of Lake Manzalah during four successive seasons (1999-2000). The study revealed that an obvious depletion of dissolved oxygen has occurred in addition to a high increase in COD and BOD in the area which received the urban and agricultural wastes from Bahr El-Bagar drain. The concentrations of the nutrient saits showed a wide fluctuation and abrupt changes due to irregular influx of different wastes. Also, high and abnormal concentrations of ammonia, nitrate and orthophosphate were recorded. The levels of trace metals in lake water were high in areas received domestic and agricultural effluents.

\section{INTRODUCTION}

Lake Manzalah is the largest and most productive among all the Egyptian brackish lakes. It is located in the north-eastern extremity of the Nile Delta. The total area of the lake is about 872 $\mathrm{Km}^{2}$ of which only $778 \mathrm{Km}^{2}$ represent open water with an average depth of about $140 \mathrm{~cm}$. The area of the lake has been steadily decreased in size since records started in the early $1900^{\circ}$ s where it was estimated as $1647 \mathrm{Km}^{2}$. Land reclamation in the west and the south of the lake is the main cause of this decrease.

Now, the lake is considered as a sink for disposing industrial and human wastes. A total amount of about 7500 million cubic meters of untreated industrial, domestic and drainage water as well as agrochemical (fertilizers and biocides) is discharged annually into the lake throngh seven main drains (Ibrahim et ai., 1997a). Hadous. 
Ramsis and Bahr El-Bagar drains contribute about $75 \%$ of the total anmal drainage water into the southern sector of the lake.

Corisequently, the quality of water in the lake basin has been affected by many factors: the most significant of which are the location of the drains and the quality of their water inflow. The appearance of the pollution problem in the lake started since 1967 by closing of the inlets, which connected the lake with the sea. This situation led to the continuous disappearance of the marine fishes from the lake.

Khali (1990) stated that the salinity and nutrients are important factors, which affect and still affect the ecology of lake Manzalah. The increase in nutrients and freshwater discharges has changed the fish community from a brackish (mixed species) to a freshwater (Tilapia) dominated one (Khalil and Salib, 1986). Ibrahim et al. (1997a) recorded three species of bottom fauna at the southern sector of lake compared by 16 species at sea-lake connection and added that the low number of species encountered is probably due to the high level of water pollution.

Previous studies on biological characteristics of the lake have been issued by Dowidar et al. (1990); El-Serafy and AbdelBaky (1990); Aboul Ezz and Abdel-Razek (1991); Ibrahim et al. (1997b); Abdel-Baky et al. (1998); Fishar (1999a,b) and Sabae (2000).

The aim of the present study was to follow up the variations in water quality and trace metals in the southern sector of the lake in addition to the inflowing drains to assess the extent of eutrophication condition in Lake Manzalah.

\section{MATERIAL AND METHODS}

The sampling stations were chosen to cover the southern sector of Lake Manzalah and its inflowing drains. Water of study area is subjected to pollution via several and rather complicated routes; arong them domestic and agricultural discharges are the most significant. Hadous-Ramsis drain has typical agricultural drainage water, which would be of moderate quality for agricultural use. However, water from Bahr El-Bagar, is quite different. Bahr ElBagar serves as a wastewater stabilizing facility for Cairo sewage, allowing this wastewater to become biologically degraded into nutrient-rich by the time it reaches the lake. 
The present study was extended from autumn 1999 to summer 2000. Six stations were determined to cover the area of investigation. Additional stations were chosen inside both HadousRamsis and Bahr El-Bagar drains. The locations of sampling stations are presented in Fig. (1).

Water samples were taken from the surface layer by using polyvinyl chloride Van Dorn bottle. Samples were preserved in an ice-box and returned immediately to be analysed. The chemical parameters were analysed according to the methods described in APHA 1995. Salinity was calculated by multiplying the value of chlorosity by 1.80655 (Jacobosen and Kundsen. 1940 ).

For total trace metals, the samples were acidified with concentrated nitric acid $(\mathrm{pH}<2)$ and then digested by nitric-perchtoric acid mixture (APHA, 1995). The total metal concentrations were determined by using Hitachi model 170-30 with graphite atomizer $(\mathrm{GA}-2)$ atomic ahsorption spectrophotometer.

\section{RESULTS AND DISCUSSION}

The present results showed a noticeable seasonal trend of temperature (17.6-24.6 and $25.0-30.5^{\circ} \mathrm{C}$ during cold and hot seasons, respectively). However, the variations in water transparency and conductivity were almost local without clear-cut seasonal trends (Table 1). Generally, the decrease of transparency in the studied area may be due to increase in phytoplankton abundance, as the water acquired a characteristic greenish color. E.C. showed positive correlation with $\mathrm{Na}, \mathrm{K}, \mathrm{Ca}$ and $\mathrm{Mg}(\mathrm{r}=0.66,0.86,0.57$ and 0.75 . respectively) and with $\mathrm{PO}_{4}{ }^{3-}, \mathrm{SO}_{4}{ }^{2-}$ and $\mathrm{NH}_{3}(\mathrm{r}=0.45,0.62$ and 0.65 . respectively).

Slightly acidic $\mathrm{pH}$ values were recorded at station 4 during autumn and in Bahr El-Bagar drain during autumn and winter seasons (Table 1). The relative decrease of $\mathrm{pll}$ may be attributed to the bacterial and fungal action in the sediment. These activities give rise to methane and hydrogen sulphide release as well as the formation of organic acids and other break down products(Elewa and Ghallab, 2000).

The values of dissolved oxygen (DO) ranged between 0.0 to $5.9 \mathrm{mgl}^{-1}$ with remarkable seasonal and site variations (Table 2). The highest values were recorded during winter and the 
lowest during summer. Obvious depletion of DO was recorded at discharge point of Bahr El-Bagar into the lake and inside the drain itself. This may be attributed to the effect of pollution by sewage and agricultural wastes discharged, as well as, biochemical decomposition of orgar ic matier. This is supported by the increase in COD at this station. As a general, the highest values of COD and BOD were observed at station 4 due to the high load of organic matter from Bahr El-Bagar drain during the different seasons (Table 2).

The bicarbonate concentrations of the lake (210.0-528.2 $\left.\mathrm{mgl}^{-1}\right)$ indicate their high productivity and consequently favorable condition for fish production (Table 3). The salinity showed large fluctuation (614-3074 $\mathrm{mgl}^{-1}$ ) at different stations with abrupt increase at the areas affected by domestic waste (Table 3 ). Thus, the fluctuation in salinity plays a key role in establishing the distribution and dynamics of the chemical water quality also, has a strong influence on the distribution of biological species (Ueda et al., 2000). Statistically, salinity shows significant correlation at $\mathrm{p} \leq 0.05$ with $\mathrm{Na}^{+}, \mathrm{K}^{+}, \mathrm{Ca}^{2+}$ and $\mathrm{Mg}^{2+}(\mathrm{r}=0.66,0.86,0.57$ and 0.75 , respectively) and with $\mathrm{PO}_{4}{ }^{3-}, \mathrm{SO}_{4}{ }^{2-}$ and $\mathrm{NH}_{3}(\mathrm{r}=0.48,0.64$ and 0.66 , respectively).

The high increase in sulphate concentrations during different seasons at station 4 and Bahr El-Bagar drain may be due to the bacterial oxidation effect of detrital organic phase present in domestic sewage (Table 3 ).

Obviously, there was an increase in the concentration of eutrophication key elements ( $\mathrm{P}$ and $\mathrm{N}$ ). Nitrate content exhibited an extremely wide range of variation (1.71-821.09 $\mathrm{gl}^{-1}$ ) (Table 4). This is mainly due to domestic wastes and agricultural runoff beside fertilizers, which are considered one of the sources of nutrients, (Macdonald et al., 1995). The depletion of nitrite at station 4 may be principally due to the its reduction to ammonia as well as, its uptake by phytoplankton in the surface water as reported by Elewa et al. (1995).

Ammonia concentrations are present in excess (1.13-20.35 $\left.\mathrm{mgl}^{-1}\right)$ with relatively higher values at station 4 than other station (Table 4). These high values are attributed to the domestic and agricultural wastes, where ammonia and bicarbonate are the final products of the bacterial decomposition of organic matter (AbdelSatar, 1998). The main factor that affects the toxicity of ammonia at this station is the dissolved oxygen depletion, as the decrease in 
dissolved oxygen increase the toxicity as reported by Deai ei al. (1991). The present results showed significant positive correlation between ammonia and E.C. $(r=0.65$, at $p \leq 0.05)$, which proved, that the ionized form is predominate in the lake water.

The ortho- and total phosphate concentrations were varied in the range of 249.32-1399.56 $\mathrm{gll}^{-1}$ ann $0.486-2.066 \mathrm{mgl}^{-1}$, respectively (Table 5). The observed high concentrations of phosphorus content at station 4 may be due to the domestic wastes discharged from Bahr EIBagar drain into this station, winich contain high amount of phosphorus resulting from the organic matter degradation (Muscutt and Wither, 1996). The high anthropogenic inputs of nutrients has led to a deteriorating water quality and caused serious problems (Yoshimural et al., 2000)

A negative significant correlation between both orthophosphate with dissolved oxygen exists $(r=-0.71$ at $p \leq 0.05)$. This suggests that under aerobic conditions, the phosphate concentration is decreased due to the consumption by rooted hydrophytes and phytoplankton as mentioned by Olsen and Sommerfeld (1977).

There are decrease in the silicate concentration during hot seasons (0.93-5.55 $\left.\mathrm{mgl}^{-1}\right)$ compared with high values recorded during cold seasons (10.29-16.34 $\mathrm{mgl}^{-1}$ ) for all stations (Table 5). This is related to the uptake of silicate by diatoms, fungi, algae, phyto- and zooplankton and fish during hot seasons as reported by Abdel-Satar, (1998).

The most predominant cation in the studied area is sodium (103.3-251.2 $\mathrm{mgl}^{-1}$ ) (Table 6). Water hardness is among the most important environmental factors which affects the toxicity of pollutants. Calcium and magnesium concentrations increase with increasing salinity. This is supported by the positive correlation between them and salinity ( $r=0.57,0.75$, respectively).

Heavy metals transported into the environment originate either from natural sources, such as wind borne soil particles, or from anthropogenic sources (Birch et al., 1996). The present results showed that the maximum value of $F e\left(6.255 \mathrm{mgl}^{-1}\right)$ was recorded at station 1 , which received the agricultural wastes discharged from Hadous-Ramsis drain (Table 7). These wastes contain high amount of uspended solids, where iron oxide are an intrinsic part of uspended solids as reported by Vander Weijden and Middelburge 1989). On the other hand, the maximum values of $\mathrm{Mn} . \mathrm{Zn}$. Cu and 
$\mathrm{Pb}\left(441.4,71.38,26.44\right.$ and $\left.70.52 \mu \mathrm{gl}^{\mathrm{l}}\right)$ were recorded at station 4 Table 7), which received domestic wastes discharged from Bahr ElBagar drain. This is agreed with those reported by Nather Khan and Lim (1994), who stated that the concentrations of the metals depend on the types mo amours of waste discharged.

The decrease in $Z \mathrm{n}$ concentration at station 4 during summer may be due to the fact that $\mathrm{Zn}$ reacts with the high concentration of $\mathrm{H}_{2} \mathrm{~S}$ to form virtually insoluble zinc sulphide under anoxic condition (Birch et al., 1996).

The relative decrease in $\mathrm{Cu}$ concentrations during cold seasons may be attributed to the formation of $\mathrm{CuO}$, that rapidly changed to amorphous $\mathrm{Cu}(\mathrm{OH})_{2}$ and precipitated at the bottom (Masoud et al., 1994).

The maximum $\mathrm{Pb}$ concentration was obtained at station 4 in which the domestic wastes contain high amount of lead in both dissolved and particulate forms. Statistically, $\mathrm{Mn}$ level shows positive correlation with $\mathrm{Cu}$ and $\mathrm{Pb}(r=0.53$ and 0.66 , respectively) and between $\mathrm{Zn} \& \mathrm{Cu}(\mathrm{r}=0.55)$ at $\mathrm{p} \leq 0.05$. Also, positive correlation between salinity and each of $\mathrm{Mn}, \mathrm{Zn}, \mathrm{Cu}$ and $\mathrm{Pb}(\mathrm{r}=0.56,0.60,0.48$ and 0.72 , respectively), and this may attributed to the decrease in sorption of these metals to solid phase with increase salinity.

Finally, we can conclude that the drains play an important role in increasing the eutrophication condition of lake water which cause serious effect on aquatic organisms. Also, the high levels of $\mathrm{Fe}, \mathrm{Mn}$ and $\mathrm{Pb}$ indicate that these values exceed the allowable maximum concentration reported by Word Health Organization $\left(0.3,0.1\right.$ and $0.05 \mathrm{mgl}^{-1}$, respectively) which might cause a public health problem.

\section{REFERENCES}

Abdel Baky, T.E; Hagras, A.E; Hassan, S.H. and Zyadah. M.A. (1998). Heavy metals concentrations in some organs of Oreochromis (Tilapia) aureus Stein in Lake Manzalah, Egypt. J. Egypt. Ger. Soc. Zool., 25: 237-256.

Abdel-Satar, A.M. (1998). Distribution of some chemical elements in River Nile environments at Great Cairo Region. Ph. D. Thesis, Faculty of Science, Cairo Univ., 249pp. 

upon the southern sector of Lake Manzalah, Egypt

Aboul Ezz, A. S. and Abdel-Razek, S. E. (1991). Heavy metal accumulation in the Tilapia nilotica and in the waters of Lake Manzalah. Egypt. J. Appl. Sci., 6 (6): 37-52.

American Public Health Association (APHA) (1995). Standard Methods for the Examination of Water and Waste Water, New York.

Birch, L., Hanselmann, K. W. and Bachofen, R. (1996). Heavy metal conservation in Lake Cadagno sediments: Historical records of anthropogenic emissions in a Meromictic Alpine Lake. Wat. Res., 30: 679-687.

Deai, J.; Yida, T.; Gong, Y.; Jianrong, Z. and Yicheng, S. (1991). Factors affecting the relationship between the NBOD values and the amounts of nitrogenous pollutants: A field study on the Lee River, Wat. Res., 25: 485-489.

Dowidar, N.M.; Hosny, C.F. and Ezzat, A.A. (1990). Mortality and survival rates of tilapias in Lake Manzalah, Egypt. Int. Symp. on Biol. and Culture of Tilapias. Alexandria, Egypt. 173-189

Elewa, A. A., Massoud, M. S. and Abdel-Halim, A. M. (1995). Limnological study on the Nile water of Egypt. Bull. NRC, Egypt, 20:437-450.

Elewa, A.A. and Ghallab, M.H. (2000). Water-sediment interaction infront of El-Rahawy drain Rossetta branch, River Nile, Egypt. Presented at $4^{\text {th }}$ international symposium on sediment quality assessment, Otsu, Japan, October 24-27.

El-Serfy, S. and Abdel-Baky, T.E. (1990). Fish catch characteristics in Lake Manzalah, Egypt. J. Appl. Sci., 5: 505-521.

Fishar, M.R.A. (1999a). Distribution and abundance of benthic assemblages in El-Gamil basin (Lake Manzalah) a) Meiobenthos, Bull. Nat. Inst. Oceanogr. Fish., A.R.E., 25: 151-165. 
Fishar, M.R.A. (1999b). Distribution and abundance of benthic assemblages in El-Gamil basin (Lake Manzalah) b) Macrobenthos, Bull. Nat. Inst. Oceanogr. Fish., A.R.E., 25: 167-180.

Ibrahim, M.A., Mona, M.H. and El-Bokty, E.E. (1997a). Abundance and distribution of bottom fauna in Lake Manzalah, Egypt. Bull. Nat. Inst. Oceanogr. Fish., A.R.E., 23: 333-349.

Ibrahim, M.A., Mousa, A.A. and El-Bokty, E.E. (1997b). Envirommental factors affecting abundance and distribution of Macrobenthic organisms in Lake Manzalah, Egypt. Bull. Nat. Inst. Oceanogr. Fish., A.R.E., 23: 315-331.

Jacobsen, T.P. and Kundsen, M. (1940). Determination of Salinity. Pứs. Scient. Ass. Oceanogr. Phus., 7-38.

Khali, M.T. and Salib, E.A. (1986). Effects of some water quality parameters on fish composition and productivity in lake Manzalah, Egypt. Proc. Zool. Soc. A.R.Egypt, 12:101-109.

Khalil, M.T., (1990). The physical and chemical environment of Lake Manzalah, Egypt. Hydrobiol, 196: 193-199.

Macdonald, A.M., Edwards, A.C., Pugh, K.B. and Balls, P.W., (1995). Soluble nitrogen and phosphorus in the River Ythan system, U.K.: Annual and seasonal trends. Wat. Res., 29: 837-846.

Masoud, M.S.; Elewa, A.A. and Awad, F.K. (1994). Distribution of some trace metals in River Nile water, Bull. Fac. Sci. Assiut Univ., 23: 67-82.

Muscutt, A.D. and Withers, P.J.A., (1996). The phosphorus content of rivers in England and Wales, Wat. Res., 30: 1258-1268.

Nather Khan, I. S. A. and Lim, R.P. (1994). Distribution of metals in the Linggi River basin, Malaysia with reference to pollution. Aust. J. Mar. Freshwater Res., 42: 435-449.

Olsen, R.D. and Sommerfeld, M.R. (1977). The plysical-chemical limnology of a desert reservoir. Hydrobiol, $53: 17-129$. 

upon the southern sector of Lake Manzalah, Egypt

Sabae, S.Z. (2000) Assessment of Microbial Pollution in Lake Manzalah, Egyp . J. Egypt. Acad. Soc. Environ. Develop., (1): 45-61.

Ueda, S.; Kawabata, H.; Hasegawa, H.; Kondo, K. (2000). Characteristics of fluctuations in salinity and water quality in brackish Lake Obuchi. Liminol., 1: 57-62.

Vander Weijden, C.H. and Middelburg, J.J. (1989). Hydrogeochemistry of the River Rhine: Long term and seasonal variability, elemental budgets, base levels and pollution. Wat. Res., 23: 1247-1266.

Yoshimura, T.; Kudo, I; Yanada, M and Matsunaga, K. (2000). Changes in the water quality in Lake Ohnuma, Hokkaido, Japan: a comparison of 1977 and 1996., Liminol., 1: 63-68. 
Table (1): Seasonal variations of E.C., transparency and pH in lake Manzalah water during 1999-2000.

\begin{tabular}{|c|c|c|c|c|c|c|c|c|c|c|c|c|}
\hline \multirow{2}{*}{ Scason } & \multicolumn{3}{|c|}{ Autumn } & \multicolumn{3}{|c|}{ Winter } & \multicolumn{3}{|c|}{ Spring } & \multicolumn{3}{|c|}{ Summer } \\
\hline & $\begin{array}{c}E . C \\
\mu \mathrm{Scm}^{-1}\end{array}$ & $\begin{array}{c}\text { Trans. } \\
\mathrm{cm} .\end{array}$ & $\mathrm{pH}$ & $\begin{array}{l}\mathrm{ECC} \\
\mu \mathrm{S} \mathrm{cm}^{-1}\end{array}$ & $\begin{array}{c}\text { Trans. } \\
\text { cm. }\end{array}$ & pH & $\begin{array}{l}\text { E.C. } \\
\mu S \mathrm{Sm}^{-1}\end{array}$ & $\begin{array}{c}\text { Trans. } \\
\mathrm{cm} .\end{array}$ & $\mathrm{pH}$ & $\begin{array}{l}\mathrm{EC} \\
\mu \mathrm{Scm}\end{array}$ & $\begin{array}{c}\text { Trans. } \\
\text { cin. }\end{array}$ & $\mathrm{pll}$ \\
\hline 1 & 1930 & 15 & 7.27 & 1960 & 18 & 7.62 & 2300 & 22 & 8.1 & 2640 & 25 & 758 \\
\hline 2 & 3810 & 30 & 7.31 & 3560 & 23 & 7.7 & 4300 & 25 & 8.08 & 2890 & 20 & 74 \\
\hline 3 & 2940 & 20 & 7.29 & 4020 & 18 & 7.6 & 2830 & 30 & 8.1 & 3510 & 30 & 7.52 \\
\hline 4 & 6090 & 10 & 6.69 & 4950 & 10 & 7.13 & 5760 & 18 & 7.6 & 3530 & 15 & 7.3 \\
\hline 5 & 2870 & 40 & 7.3 & 2420 & 22 & 7.62 & 2780 & 30 & 8.07 & 5410 & 25 & 7.9 \\
\hline 6 & 2820 & 35 & 7.3 & 2050 & 23 & 7.67 & 2670 & 25 & 8.08 & 2610 & 28 & 7.6 \\
\hline $\mid \begin{array}{l}\text { Hadous } \\
\text { Yxamsic drain }\end{array}$ & 1240 & 13 & 7.01 & 1590 & 15 & 7.2 & 2200 & 20 & 7.9 & 2960 & 20 & 7.4 \\
\hline Bahr Et & 2580 & 8 & 6.05 & 4750 & 8 & 6.8 & 5720 & 14 & 7.2 & 6560 & 12 & 7.1 \\
\hline
\end{tabular}

Table (2): Seasonal variations of DO, COD and BOD concentrations (mgl ${ }^{2}$ ) in lake Manzalah water duriug 1999-2000.

\begin{tabular}{|c|c|c|c|c|c|c|c|c|c|c|c|c|}
\hline & \multicolumn{3}{|c|}{ Autumn } & \multicolumn{3}{|c|}{ Winter } & \multicolumn{3}{|c|}{ Spring } & \multicolumn{3}{|c|}{ Summer } \\
\hline & DO) & COD & $\overline{\mathrm{BOI}}$ & 100 & COD & BOD & $\overline{\mathrm{DO}}$ & COD & BOD & $\overline{100}$ & COD & BOD \\
\hline 1 & 5.8 & 13.8 & 6.2 & 5.8 & 6.4 & 3.6 & 4.8 & 7.2 & 3.5 & 3.1 & 4.0 & 21 \\
\hline 2 & 5.8 & 12.8 & 6.0 & 5.6 & 6.4 & 3.7 & 4.8 & 8.8 & 4.3 & 3.5 & 10.0 & 4.9 \\
\hline 3 & 5.9 & 14.1 & 7.0 & 5.6 & 6.0 & 3.3 & 5.0 & 6.8 & 3.8 & 3.4 & 9.6 & 4.6 \\
\hline 4 & 0.0 & 23.4 & 13.4 & 1.8 & 19.6 & 10.5 & 0.0 & 21.4 & 11.8 & 0.0 & 18.9 & 11.1 \\
\hline 5 & 5.9 & 13.6 & 6.3 & 5.9 & 4.4 & 2.1 & 5.6 & 14.4 & 6.9 & 4.1 & 12.2 & 7.2 \\
\hline 6 & 5.7 & 9.2 & 4.6 & 5.9 & 3.2 & 1.4 & 5.4 & 10.4 & 5.3 & 4.6 & 9.2 & 4.5 \\
\hline adnets. & 5.1 & 12.6 & 6.5 & 5.3 & 7.6 & 3.3 & 30 & 9.6 & 4.3 & 3.06 & 12.0 & 5.9 \\
\hline $\begin{array}{l}\text { Bahe al. } \\
\text { Bagat draing }\end{array}$ & 0.0 & 30.4 & 16.2 & 0.5 & 20.8 & 12.1 & 0.0 & 24.8 & 15.1 & 0.0 & 19.8 & 10.9 \\
\hline
\end{tabular}

Table (3): Scasonal variations of bicarbonate, salinity and sulphate concentrations

(mgl') in lake Manzalah water during 1999-2000.

\begin{tabular}{|c|c|c|c|c|c|c|c|c|c|c|c|c|}
\hline & \multicolumn{3}{|c|}{ Antumn } & \multicolumn{3}{|c|}{ Winter } & \multicolumn{3}{|c|}{ Spring } & \multicolumn{3}{|c|}{ Summer } \\
\hline & $\mathrm{HCO} \mathrm{O}_{3}$ & Salitity & $\mathrm{SO}_{1}^{2}$ & $\mathrm{ICO}_{3}$ & Salinity & $\mathrm{SO}_{4}$ & $\mathrm{HCO}_{3}$ & Salinit & $\mathrm{SO}_{4}^{2}$ & $\mathrm{HCO}_{3}$ & Salinity & $\mathrm{SO}_{4}^{2}$ \\
\hline 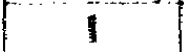 & 528.2 & 614 & 176.4 & 335.4 & 820 & 157.8 & 210.0 & 722 & 175.1 & 340.2 & 922 & 188.2 \\
\hline 2 & 408.1 & 1537 & 172.4 & 21.8 & 192 & 187.0 & 25.0 & 15 & 198.5 & 372.1 & 1434 & 167.0 \\
\hline 3 & 480.4 & 1225 & 221.5 & 361.6 & 2099 & 184.2 & 2150 & 1332 & 125.7 & 344.6 & 1563 & 155.8 \\
\hline 4 & 432.3 & 3074 & 252.0 & 258.9 & 2715 & 208.2 & 240.6 & 2767 & 232.1 & 332.8 & 2279 & 231.9 \\
\hline$\xi$ & 410.1 & 1166 & 198.9 & 335.6 & 1127 & 159.1 & 225.0 & 1537 & 184.6 & 220.2 & 2126 & 191.9 \\
\hline 6 & 443.0 & 1127 & 196.3 & 309.8 & 896 & 176.4 & 225.0 & 1178 & 185.4 & 340.1 & 1485 & 174.3 \\
\hline is & 508.0 & 537 & 261.3 & 309.6 & 769 & 143.2 & 2050 & 973 & 161.7 & 2880 & 973 & 164.7 \\
\hline $\begin{array}{l}\text { Bahr FI- } \\
\text { Bagar drain }\end{array}$ & 384.0 & 3236 & 253.6 & 361.2 & 2920 & 236.1 & 300.0 & 2817 & 235.2 & 320.0 & 3074 & 238.9 \\
\hline
\end{tabular}


Table (4): Seasonal variations of nitrite, nitrate and ammonia concentrations

in lake Manzalah water during 1999-2000.

\begin{tabular}{|c|c|c|c|c|c|c|c|c|c|c|c|c|}
\hline & \multicolumn{3}{|c|}{ Autumn } & \multicolumn{3}{|c|}{ Winter } & \multicolumn{3}{|c|}{ Spring } & \multicolumn{3}{|c|}{ Summer } \\
\hline & $\begin{array}{c}\mathrm{NO}_{2} \\
\left(\mu \mathrm{I}^{-9}\right)\end{array}$ & $\begin{array}{l}\mathrm{NO}_{3}^{-} \\
\left(\mu \mathrm{gl}^{-1}\right)\end{array}$ & $\begin{array}{c}\mathrm{NH}_{3} \\
\left.(\mathrm{mgl})^{-1}\right)\end{array}$ & $\begin{array}{c}\mathrm{NO}_{2}^{-} \\
\left(\mu \mathrm{gl}^{\prime \prime}\right)\end{array}$ & $\begin{array}{l}\mathrm{NO}_{3} \\
\left(\mu \mathrm{gl}^{-1}\right)\end{array}$ & $\begin{array}{c}\mathrm{NH}_{3} \\
\left(\mathrm{mgl}^{-1}\right) \\
\end{array}$ & $\begin{array}{c}\mathrm{NO}_{2}^{-} \\
\left(\mu \mathrm{gl}^{-1}\right)\end{array}$ & $\begin{array}{l}\mathrm{NO}_{3}^{-} \\
\left(\mu \mathrm{gl}^{-}{ }^{-7}\right)\end{array}$ & $\begin{array}{c}\mathrm{NH}_{3} \\
\left(\mathrm{mgl}^{-1}\right)\end{array}$ & $\begin{array}{c}\mathrm{NO}_{2} \\
\left(\mu \mathrm{gl}^{\prime}\right)\end{array}$ & $\begin{array}{c}\mathrm{NO}_{3}^{-} \\
\left(\mu \mathrm{gl}^{-1}\right)\end{array}$ & {$\left[\begin{array}{c}\mathrm{NH}_{3} \\
\left(\mathrm{mgl}^{-1}\right)\end{array}\right.$} \\
\hline 1 & 428 & 27.9 & 2.59 & 185 & 393.1 & 2.40 & 136 & 53.1 & 5.98 & 284 & 10.8 & 7.30 \\
\hline 2 & 217 & 117.7 & 1.13 & 147 & 262.8 & 5.18 & 68 & 47.9 & 13.87 & 217 & 15.9 & 3.70 \\
\hline 3 & 320 & 11.4 & 2.29 & 96 & 628.5 & 5.06 & 134 & 10.9 & 7.03 & 320 & 14.8 & 3.31 \\
\hline 4 & 22 & 17. 1 & 14.80 & 9 & 821.0 & 6.75 & 9 & 22.8 & 20.35 & 22 & 1.7 & 12.19 \\
\hline 5 & 36 & 54.2 & 1.15 & 80 & 779.9 & 2.61 & 127 & 24.5 & 5.67 & 26 & 7.4 & 3.46 \\
\hline 6 & 42 & 63.4 & 1.71 & 79 & 491.3 & 3.05 & 29 & 33.1 & 3.26 & 83 & 30.2 & 2.55 \\
\hline $\begin{array}{l}\text { Yladous- } \\
\text { Ramsis draja }\end{array}$ & 129 & 148.5 & 1.65 & 177 & 289.1 & 7.03 & 19 & 54.8 & 7.81 & 469 & 70.2 & 4.91 \\
\hline $\begin{array}{l}\text { Bahr El- } \\
\text { Bagar drain }\end{array}$ & 20 & 77.7 & 19.14 & 4 & 542.8 & 9.31 & 4 & 42.8 & 22.84 & 101 & 3.4 & 14.74 \\
\hline
\end{tabular}

Table (5): Seasonal variations of orthophosphate, total phosphate (t-P) and

silicate concentrations in lake Manzalah water during 1999-2000.

\begin{tabular}{|c|c|c|c|c|c|c|c|c|c|c|c|c|}
\hline & \multicolumn{3}{|c|}{ Autumn } & \multicolumn{3}{|c|}{ Winter } & \multicolumn{3}{|c|}{ Spring } & \multicolumn{3}{|c|}{ Summer } \\
\hline & $\begin{array}{l}\mathrm{PO}_{4}^{3-} \\
\left(\left.\mu\right|^{-1}\right)\end{array}$ & $\begin{array}{c}\mathrm{t}-\mathbf{P} \\
\left(\mathrm{mgl}^{-1}\right)\end{array}$ & $\begin{array}{l}\mathrm{SiO}_{3}{ }^{2-} \\
\left(\left.\mathrm{mg}\right|^{-1}\right)\end{array}$ & $\begin{array}{l}\mathrm{PO}_{4}{ }^{3} \\
\left(\mu \mathrm{gl}^{-1}\right)\end{array}$ & $\begin{array}{c}\mathrm{t}-\mathrm{P} \\
\left.(\mathrm{mg})^{-1}\right)\end{array}$ & $\begin{array}{l}\mathrm{SiO}_{3}{ }^{-2} \\
\left(\mathrm{mgl}^{-1}\right)\end{array}$ & $\begin{array}{l}\mathrm{PO}_{4}{ }^{3-} \\
\left(\mu I^{-1}\right)\end{array}$ & $\begin{array}{c}\mathrm{t}-\mathrm{P} \\
\left.(\mathrm{mgl})^{\prime}\right)\end{array}$ & $\begin{array}{l}\mathrm{SiO}_{3}{ }^{2-} \\
\left(\mathrm{mgl}^{-1}\right)\end{array}$ & $\begin{array}{l}\mathrm{PO}_{4}^{3-} \\
\left(1 \mathrm{~g}^{\prime \prime}\right)\end{array}$ & $\begin{array}{c}\mathrm{t}-\mathrm{P} \\
\left.(\mathrm{mgl})^{-1}\right)\end{array}$ & $\begin{array}{l}\mathrm{SiO}_{3}{ }^{2} \\
\left(\mathrm{mgl}^{-1}\right)\end{array}$ \\
\hline 1 & 511.5 & 0.721 & 10.29 & 471.6 & 0.822 & 11.57 & 714.5 & 1.209 & 0.93 & 619.4 & 0.915 & 3.92 \\
\hline 2 & 392.0 & 0.679 & 10.38 & 458.8 & 0.738 & 12.73 & 939.4 & 2.066 & 2.53 & 447.2 & 0.832 & 3.19 \\
\hline 3 & 249.3 & 0.509 & 11.54 & 334.1 & 0.698 & 16.34 & 656.7 & 1.334 & 2.79 & 447.2 & 0.835 & 5.29 \\
\hline 4 & 1116.8 & 1.423 & 12.50 & 289.1 & $0.589^{\circ}$ & 11.48 & 1399.5 & 1.905 & 5.08 & 1157.9 & 1.868 & 5.55 \\
\hline 5 & 314.8 & 0.584 & 10.84 & 296.8 & 0.486 & 12.21 & 726.1 & 1.233 & 3.72 & 303.3 & 0.740 & 3.22 \\
\hline 6 & 344.4 & 0.643 & 10.43 & 284.0 & 0.627 & 11.48 & 484.5 & 1.103 & 2.29 & 307.1 & 0.801 & 2.73 \\
\hline $\begin{array}{l}\text { Mindous. } \\
\text { Ramais drnin }\end{array}$ & 396.6 & 0.905 & 11.16 & 467.8 & 0.796 & 10.78 & 729.9 & 2.368 & 5.49 & 490.6 & 1.079 & 2.73 \\
\hline $\begin{array}{l}\text { Bahr El- } \\
\text { Bagar drain }\end{array}$ & 1220.9 & 1.989 & 13.08 & 687.5 & 1.129 & 14.70 & 2542.0 & 4.544 & 6.19 & 1196.6 & 1.979 & 4.34 \\
\hline
\end{tabular}

Table (6): Seasonal variations of major cations concentrations $\left(\mathrm{mgl}^{-1}\right)$ in lake

Manzalah water during 1999-2000.

\begin{tabular}{|c|c|c|c|c|c|c|c|c|c|c|c|c|c|c|c|c|}
\hline & \multicolumn{4}{|c|}{ Autumn } & \multicolumn{4}{|c|}{ Winter } & \multicolumn{4}{|c|}{ Spring } & \multicolumn{4}{|c|}{ Sumner } \\
\hline & $\mathrm{Na}$ & K & $\mathrm{Ca}$ & $\mathrm{Mg}$ & $\mathrm{Na}$ & $\mathrm{K}$ & $\overline{\mathrm{Ca}}$ & $\mathrm{Mg}$ & $\mathrm{Na}$ & $K$ & $\mathrm{Ca}$ & $\overline{\mathrm{Mg}}$ & $\mathrm{Na}$ & $\mathrm{K}$ & $\mathrm{Ca}$ & $\mathrm{Mg}$ \\
\hline 1 & 103.3 & 7.93 & 80.2 & 70.8 & 121.6 & 11.33 & 81.7 & 71.0 & 156.5 & 13.33 & 78.5 & 67.1 & 200.4 & 11.92 & 48.0 & 128.4 \\
\hline 2 & 149.7 & 14.54 & 119.9 & 120.2 & 181.7 & 18.49 & 91.3 & 131.3 & 222.5 & 12.30 & 117.0 & 111.8 & 234.3 & 13.92 & 48.0 & 141.0 \\
\hline 3 & 131.9 & 11.89 & 91.3 & 88.6 & 234.9 & 21.47 & 101.0 & 146.8 & 177.3 & 20.50 & 88.1 & 72.9 & 239.9 & 15.92 & 56.1 & 146.8 \\
\hline 4 & 185.3 & 22.47 & 165.2 & 145.9 & 240.7 & 26.44 & 92.9 & 167.3 & 250.4 & 25.63 & 155.5 & 135.2 & 251.2 & 20.31 & 80.1 & 175.1 \\
\hline 5 & 130.1 & 13.22 & 89.9 & 87.9 & 178.1 & 14.15 & 78.5 & 99.2 & 175.6 & 20.39 & 80.16 & 77.8 & 248.4 & 20.98 & 83.8 & 172.1 \\
\hline 6 & 126.5 & 13.22 & 88.8 & 86.9 & 166.6 & 14.51 & 105.8 & 63.2 & 170.4 & 14.35 & 73.7 & 82.6 & 237.1 & 17.92 & 40.0 & 149.8 \\
\hline lous & 100.8 & 8.93 & 78.2 & 70.2 & 134.5 & 10.34 & 75.3 & 78.7 & 142.5 & 14.35 & 65.3 & 61.2 & 146.8 & 11.52 & 56.1 & 116.7 \\
\hline $\begin{array}{l}\text { ahr E!- } \\
\text { agar drain }\end{array}$ & 206.7 & 2370 & 1018 & 163.2 & 240.1 & 28.46 & 109.0 & 18 & 248.6 & 21.53 & 68.7 & 59.0 & 256.8 & 19.99 & 141.0 & 186.7 \\
\hline
\end{tabular}




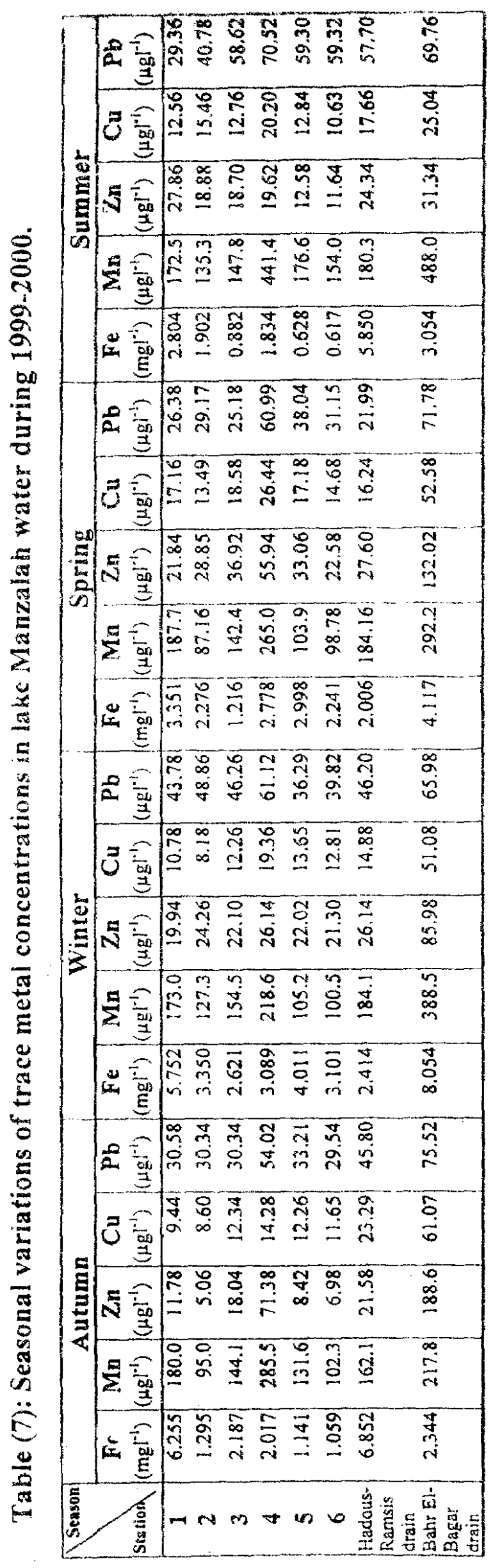




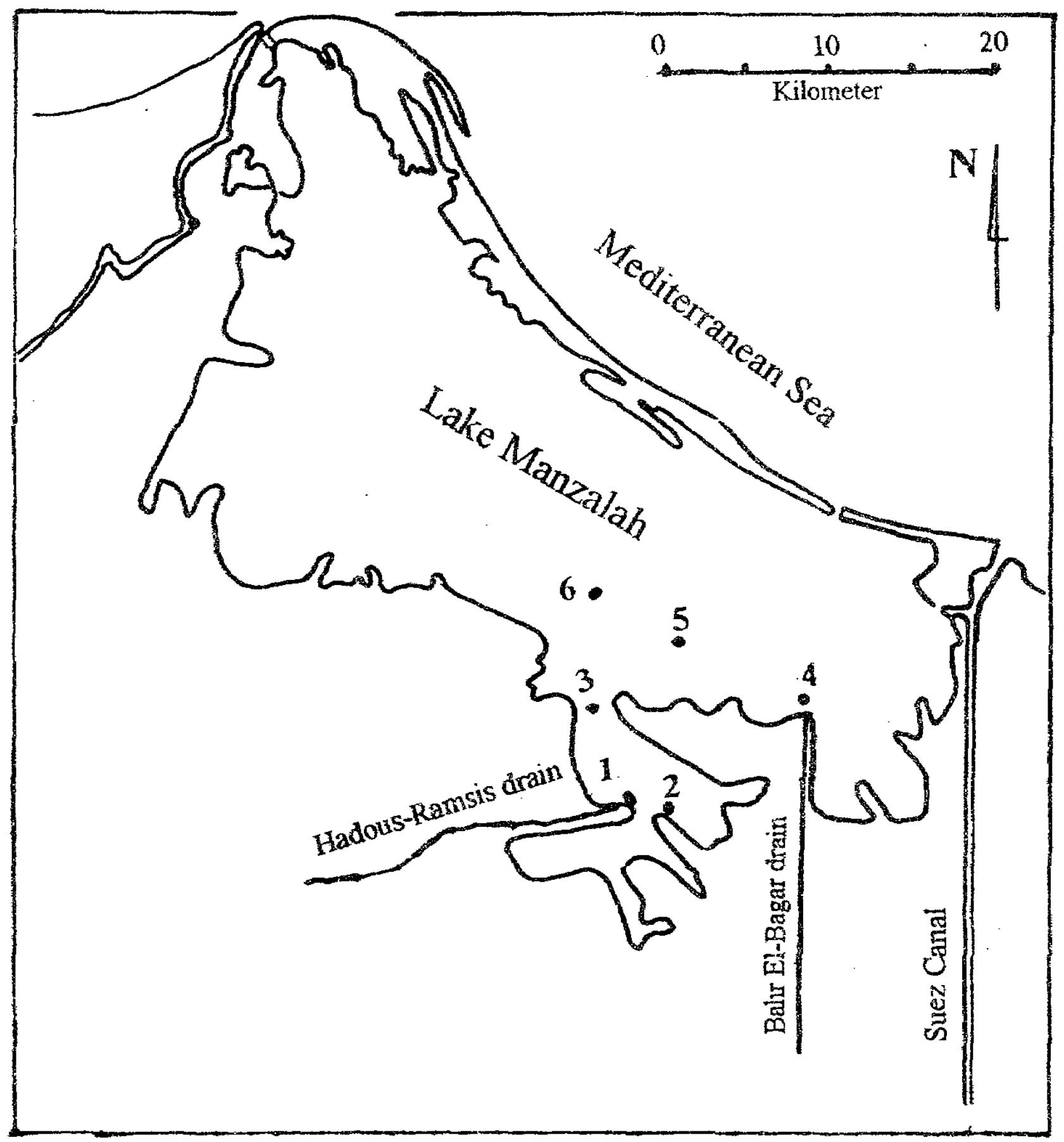

Fig. (1): Water quality sampling stations in Lake Manzalah 